STAINS ON MY NAME, WAR IN MY VEINS 



\section{STAINS ON}

MY NAME,

WAR IN

MY VEINS

Guyana and

the Politics

of Cultural

Struggle

BRACKETTE F. WILLIAMS

DUKE UNIVERSITY PRESS

Durham and London 1991 
(C) 1991 Duke University Press

All rights reserved

Printed in the United States of America on acid-free paper $\infty$

Library of Congress Cataloging-in-Publication Data appear on the last page of this book.

Third printing, 1999 


$$
\begin{gathered}
\text { To my motber, } \\
\text { Learoa Williams, and } \\
\text { to the memory of my father, } \\
\text { Jodie Williams }
\end{gathered}
$$


